\title{
Oral Cavity Carcinoma
}

National Cancer Institute

\section{Source}

National Cancer Institute. Oral Cavity Carcinoma. NCI Thesaurus. Code C8990.

A carcinoma arising in the oral cavity. Most oral cavity carcinomas are squamous cell carcinomas of the tongue, buccal mucosa, or gums. Less frequent morphologic variants include mucoepidermoid carcinoma and adenocarcinoma. 